\title{
SOME EFFECTS OF SIMULTANEOUS ADMINISTRATION OF CRUDE AQUEOUS EXTRACTS OF MANGIFERA INDICA LEAVES AND TETRACYLINE ON THE LIVER OF ADULTS WISTAR RATS
}

\author{
${ }^{1}$ Peterson M.S. Atiba, ${ }^{2}$ Adesina J. Ajibade, ${ }^{3}$ Peter B. Olaitan
}

${ }^{1}$ Department of Anatomy, College of Medicine, University Of Ibadan, Ibadan, Oyo State. Nigeria.

${ }^{2}$ Department of Anatomy, College of Health Sciences, Ladoke Akintola University Of Technology, Ogbomoso, Oyo State. Nigeria.

${ }^{3}$ Department of Surgery, College of Health Sciences, Ladoke Akintola University Of Technology, Ogbomoso, Oyo State. Nigeria.

Correspondence to ATIBA P.M.S P.O BOX 56, OSOGBO, OSUN STATE, NIGERIA. petersonatiba@yahoo.com. +2348030947446

\begin{abstract}
This study was designed to determine the simultaneous effect of Mangifera indica crude aqueous extract and the therapeutic dose of tetracycline on some hepatic enzymes (ALT and AST) and histology of the liver of adult wistar rats. 25 wistar rats were divided into 5 groups: Group A was untreated and served as control group, group B was treated with only $2 \mathrm{~mL}$ of mango leaves decoction, group C was treated with only $5.4 \mathrm{mg} / \mathrm{kg}$ of tetracycline, group D was treated with $1 \mathrm{~mL}$ of mango leaves decoction and $4.8 \mathrm{mg} / \mathrm{kg}$ of tetracycline and group $E$ was treated with $3 \mathrm{~mL}$ of mango leaves decoction and $7.7 \mathrm{mg} / \mathrm{kg}$ of tetracycline simultaneously. The administration period lasted for only 14 days which was given gavagely and the rats were sacrificed on the 15th day by cervical dislocation. The liver was removed, fixed in $10 \%$ formal saline and stained in $\mathrm{H}$ and $\mathrm{E}$. The transaminase enzymes (the AST and ALT) were measured to determine possible changes in their hepatic leaves. The result shows that the crude aqueous extract of mango levels has adverse effect on the morphology and some hepatic enzyme (ALT and AST) of the liver (such as enlargement of the central vein, reduction in the size of sinusoids), the therapeutic dose of the tetracycline have no detrimental effect on the morphology and the hepatic enzymes of the liver. In conclusion, the extract of mango leaves decoction has adverse effect on the liver histology and the therapeutic dosage of tetracycline has no adverse effect on the histology of the liver.
\end{abstract}

Keywords: Mango leaves, Tetracycline, Liver histology, Liver enzymes (AST and ALT)

\section{INTRODUCTION}

Mangifera indica (Mango) belongs to the family Anacardiaceae. Mangifera indica L. is a large evergreen tree, which has been introduced wherever the climate is sufficiently warm and damp and is now completely naturalized in many parts of tropic and subtropic (Ross, 1999). Mangiferin, a pharmacologically-active compound of Mangifera indica, is widely distributed in the leaves and bark of Mangifera indica (Yoshimi et al., 2001). The bark, roots and leaves of $M$. indica are of traditional medicinal importance throughout the globe (Ross, 1999). Naturally, mango leaves extract are said to have antitussive and expectorant effects which are rarely reported.

Tetracycline is a broad-spectrum antibiotic employed clinically in the treatment of bacterial infections. Tetracycline contains a

Submitted $7^{\text {th }}$ June 2016, revised on $7^{\text {th }}$ September 2016. Published online $12^{\text {th }}$ June 2017. To cite: Atiba PMS, Ajibade AJ, Olaitan PB. Some Effects Of Simultaneous Administration Of Crude Aqueous Extracts Of Mangifera Indica Leaves And Tetracyline On The Liver Of Adults Wistar Rats ...934 -942. 
four-ring structure and act by preventing attachment of tRNA to the mRNA-ribosomal complex. It is known to cause or induce testicular damage and a number of biochemical dysfunctions and suspected to induce testicular damage to animals but there is paucity of data on its effect and mechanism of action on the male reproductive system (Farombi et al, 2008).

Liver is the largest organ in the mammalian body. It is the centre of all metabolic activities in the body. The micromorphological features of the liver is highlighted by the lobules and their sinusoids that are lined with highly active Kupffer cells, central veins and hepatocyte plates that are closely associated with the terminal lymphatics and bile canaliculi (Webster and Webster, 1974; Berne \& Levy, 1998; Costanzo, 1998).

While the craze for natural products has its merits, care must be taken not to consume plants or plant extracts that could have deleterious effects on the body, either in the short term or in the long term (Omonkhua and Onoagbe, 2008).

\section{MATERIALS AND METHODS}

\section{Location and duration of study}

The protocols were carried out according to the guidelines for care and use of laboratory animals as approved by LAUTECH ethics committee for animals. This study was conducted at the animal house of the Department of Human Anatomy, LAUTECH, Ogbomoso, Oyo State, Nigeria. The rats were placed in a room temperature-controlled room with 12:12 light-dark cycle. The preliminary studies, animal acclimatization, drug procurement, actual animal experiment and evaluation of results, lasted for a period of three months. However, the actual administration of the drug to the test animals lasted for two weeks.

\section{Care of wistar rats}

Twenty-five Wistar rats weighing $150-290 \mathrm{~g}$ were used for this experimental design. The experimental animals were housed in standard plastic cages, fed with mash feed diet and water once daily. The experimental animals were randomised and divided into five groups.

\section{Collection of medicinal plant and Preparation of aqueous extract}

The aqueous extract of Mangifera indica leaves were obtained, then air-dried for six weeks. $1000 \mathrm{~g}$ of the mango leaves were obtained.The dried sample was pulverized using mortar and pestle. The resulting powder material was used in the extraction process. Extraction was carried out using the method described by (Harbourne, 1972; Ekpe et al., 1990; Uhegbu et al., 2005; Nwinuka et al., 2008) and modified for use for the purpose of this study.

\section{Experimental design and Grouping}

After acclimatization period, rats were weighed and randomly divided into five groups comprising five animals in each group as follows:

Group A: Rats were given stock diet and water ad libitum, they served as control.

Group B: Experimental animals were given stock diet and gavagely given $2 \mathrm{~mL}$ of MI extracts (MIE) for a period of 14days.

Group C: Experimental animals were given stock diet, gavagely given $5.4 \mathrm{mg} / \mathrm{kg}$ of tetracycline for a period of 14days.

Group D: Experimental animals were given stock diet, gavagely given $1 \mathrm{~mL}$ of Mango 
leaves aqueous extract and $4.8 \mathrm{mg} / \mathrm{kg}$ of tetracycline for a period of 14 days.

Group E: Experimental animals were given stock diet, gavagely given $3 \mathrm{~mL}$ of Mango leaves aqueous extract and $7.7 \mathrm{mg} / \mathrm{kg}$ of tetracycline for a period of 14 days.

\section{Preparation of Drug}

Tetracycline tablets were bought from Sumther Pharmacy, Ogbomoso, Nigeria. Doses for rats weighing between $0.15 \mathrm{~kg}$ to $0.29 \mathrm{~kg}$ were calculated to be $5.4 \mathrm{mg}, 4.8 \mathrm{mg}$ and $7.7 \mathrm{mg}$ with respect to the $250-500 \mathrm{mg}$ of human being of average body weight of $70 \mathrm{~kg}$ in 2-3 doses per day.

\section{Administration of Drugs}

Tetracycline capsules dissolved fully in distilled water, were given to each animal in the experimental group according to the concentration that corresponds to the required doses for a period of 14 days orally with the aid of an oral cannula. The animals received this drug once daily.

\section{Procedures for animal sacrifice and tissues harvest}

The animals were sacrificed by cervical dislocation on the $15^{\text {th }}$ day. Blood was collected from the heart for biochemical analysis of hepatic enzymes and the tissues (liver) were harvested immediately for histological analysis after tetracycline and mango leaves extract had been administered for 14 days. The livers were immediately fixed in $10 \%$ formol-saline.

\section{Histological Processing of the liver tissue}

The liver from each group was removed and fixed in $10 \%$ formol-saline which consists of the following: $200 \mathrm{ml}$ of $40 \%$ formaladeheyde, $18 \mathrm{~g}$ of $\mathrm{NaCl}, 1800 \mathrm{~mL}$ of distilled water. Automated tissue processor was used in the processing of the liver tissue after which the procedures were carried on the liver tissue (which includes fixation, dehydration, clearing, infiltration and embedding). The tissues were sectioned using microtome. The sections were stained in $\mathrm{H}$ and $\mathrm{E}$ stain. The stained tissues were viewed through light microscope.

\section{Enzyme Assays}

The glutamic transaminase enzymes; serum glutamate oxaloacetate transaminase (GOT) and serum glutamate pyruvate transaminase (GPT), catalyse the transfer of the amino group of glutamic acid to oxaloacetic acid in reversible reactions. The transaminase activity is proportional to the amount of oxalate or pyruvate formed over a definite period of time and is measured by reaction with 2, 4-Dinitrophenylhydrazine (DNPH) in alkaline solution.

After the blood was aspirated from the apex of the heart into plain tubes which was placed in an ice rack, the blood was centrifuged to collect the serum which later was put in freezer for further analysis.

Estimation of AST activities and ALT activities was done using Reitman-Frankel method (Widmann, 1980).

\section{Photomicrography of the tissues}

Photomicrography is the process of taking photographs through a microscope; a camera is mounted directly above the microscope's eyepiece. Normally the camera does not contain a lens because the microscope itself acts as the lens system. The photomicrographs of the tissues were at $\times 100$ magnification.

\section{Statistical analysis}

The data obtained from this study were analyzed using the Statistical Package for Social Sciences (SPSS for windows, version 19.0) and Microsoft Excel (windows 2007). Comparisons were made between control and 
experimental groups using student's t-test. Values of less than 0.05 were regarded as statistically significant.

\section{RESULT}

\section{The weight distribution of the animals}

The weight difference (initial weight minus final weight) in the animals were taken and analysed. There was a significant difference (body weight difference) among the different groups of the experimental animals. There was increase in body weight among all the groups of the wistar rats i.e. there was no reduction in body weight among those administered with crude aqueous extracts of mango leaves, tetracycline, and combination of the crude aqueous extract+tetracycline (as shown in table 1).

\section{Table 1: The body weight is represented as Mean \pm S.E.M}

\begin{tabular}{llll}
\hline Groups & \multicolumn{1}{c}{ Initial mean } & \multicolumn{1}{c}{$\begin{array}{c}\text { Final mean } \\
\text { weight }(\mathrm{g})\end{array}$} & $\begin{array}{c}\text { Percentage } \\
\text { gain/loss }(\%)\end{array}$ \\
\hline A & $143.5 \pm 4.15$ & $144.5 \pm 7.27$ & +0.69 \\
B & $155 \pm 8.52$ & $165 \pm 9.36$ & +6.45 \\
C & $190 \pm 9.08$ & $202 \pm 11.24$ & +6.84 \\
D & $167 \pm 3.74$ & $189 \pm 9.40$ & +13.17 \\
E & $270 \pm 26.32$ & $287 \pm 27.51$ & +6.30 \\
\hline
\end{tabular}

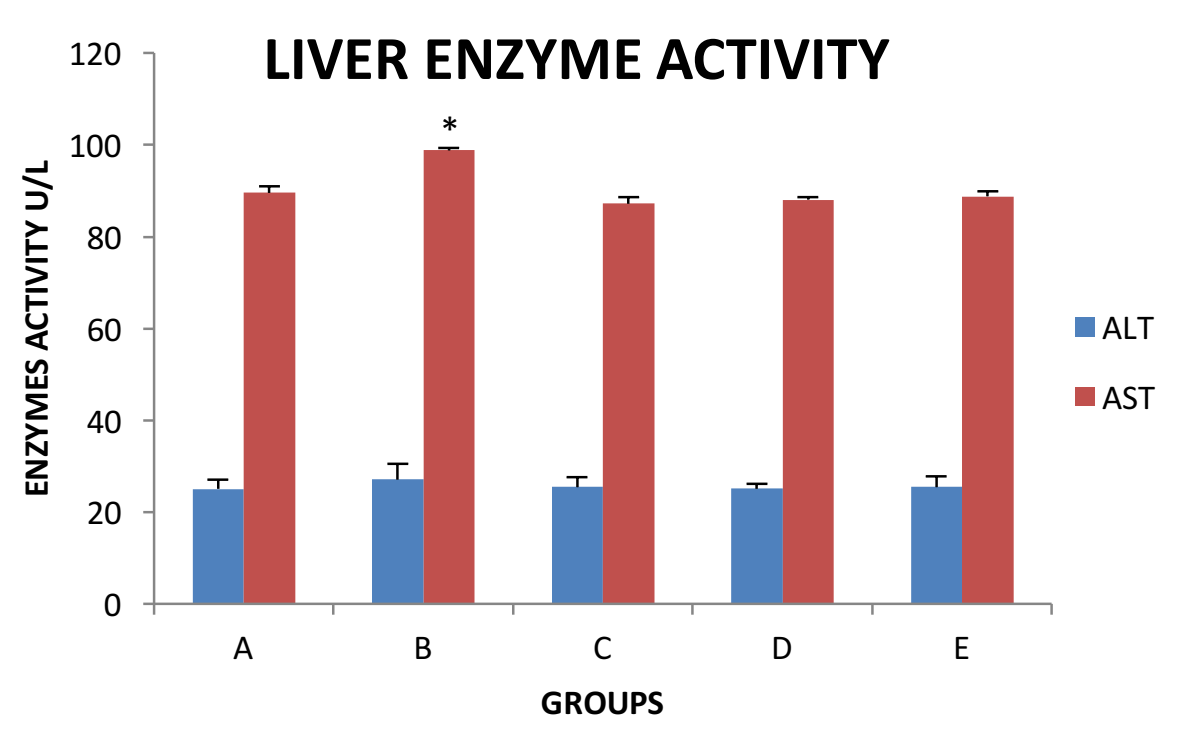

Figure 1: The enzyme activity of each group is represented as Mean \pm S.E.M; the $p$-value is significant as $<0.05$.* represent value significantly different from group $A$.

\section{Liver enzyme activity}

The liver biomarkers employ in this enzyme analysis were alanine transaminase (ALT) and aspartate transaminase (AST). Group A, the ALT activity was obtained at $25 \pm 2.14 \mathrm{U} / \mathrm{L}$ while the AST activity was obtained at 89.2 $\pm 1.32 \mathrm{U} / \mathrm{L}$. Group B, the ALT activity was 
obtained at $27.4 \pm 3.34 \mathrm{U} / \mathrm{L}$ while the AST activity was obtained at $98.8 \pm 0.56 \mathrm{U} / \mathrm{L}$. Group C, the ALT activity was obtained at $25.5 \pm 2.15 \mathrm{U} / \mathrm{L}$ while the AST activity was obtained at $87.2 \pm 1.40 \mathrm{U} / \mathrm{L}$. Group D, the ALT activity was obtained at $25.1 \pm 1.00 \mathrm{U} / \mathrm{L}$ while the AST activity was obtained at $88.0 \pm 0.56$ U/L. Group E, the ALT activity was obtained at $25.5 \pm 2.25 \mathrm{U} / \mathrm{L}$ while the AST activity was obtained at $88.8 \pm 1.04 \mathrm{U} / \mathrm{L}$ (as shown in figure 1).

\section{The histology of the liver}

Group A (figure 2A) shows liver section of clean venules (white arrow), normal

Figure 2A

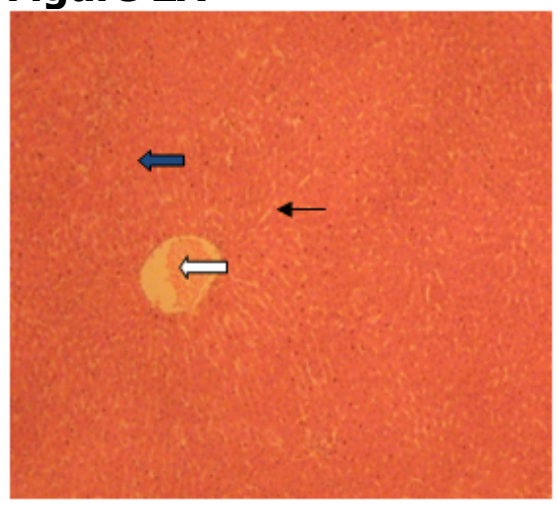

Figure 3A

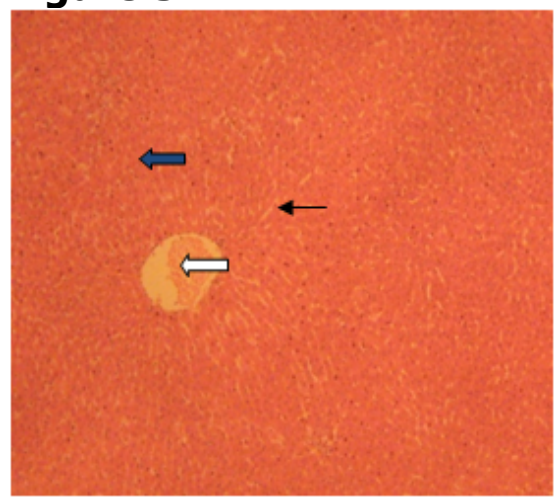

Figure 4A hepatocytes (blue arrow) and sinusoids with no inflammatory cells. Group B (figure 2B) shows liver section showing blood congestion within the central vein (white arrow). The hepatocyte and the sinusoids are normal (black arrow). Group C (figure 3B) shows liver section of a normal central vein(white arrow), normal hepatocytes (black arrow) and sinusoids with no inflammation. Group D (figure 4B) shows liver section of an enlarged central vein (white arrow), a closed sinusoid (black arrow) and the hepatocytes. Group E (figure 5A) shows liver section of an enlarged burst central vein (white arrow), shrunken sinusoid (black arrow) and the hepatocytes.

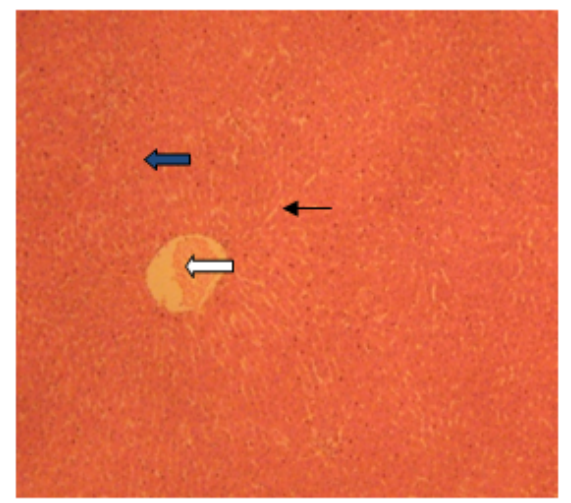

Figure 5A

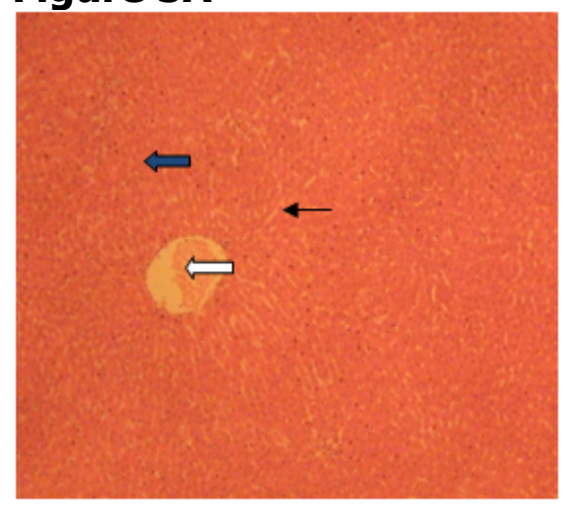

Figure 2B 


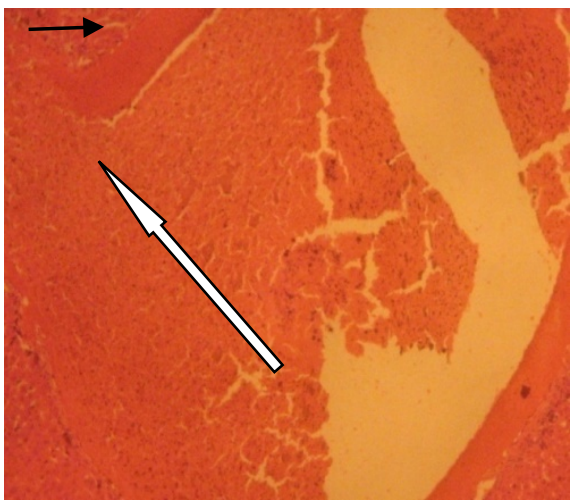

Figure 3B

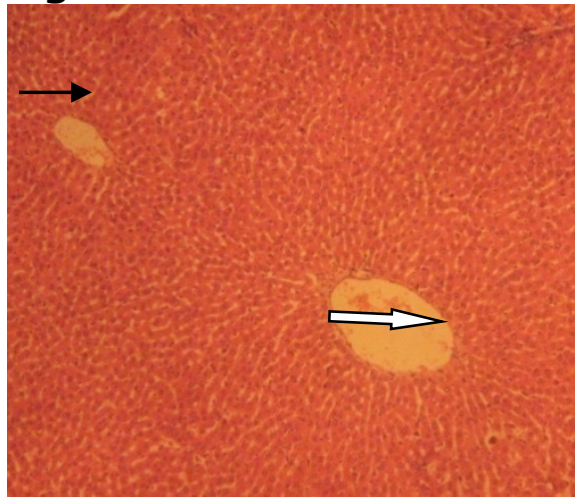

Figure 4B

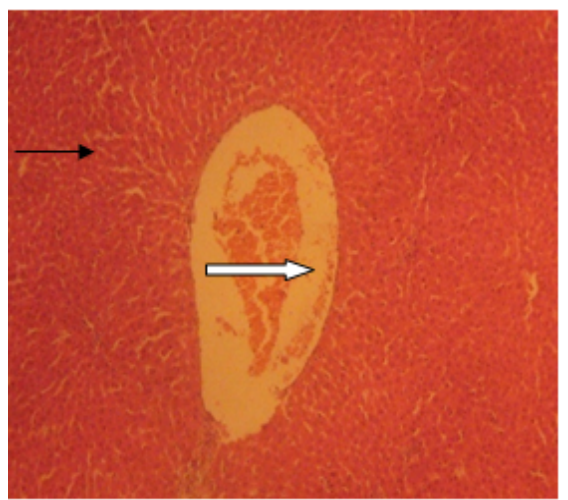

Figure 5B

\section{DISCUSSION}

The body weight of the rats as presented (in table 1) in each group showed an increase between initial and final body weight among all the groups. There were no significant differences ( $P>0.05$ ) among Groups B-E as compared against group A (Zhang et al., 2014). Therefore, therapeutic dose of tetracycline and crude aqueous extract of Mangifera indica leaves have no detrimental effect on the body weights of rats on a shortterm usage.

The histological result of this study found there was no damage to the liver cytoarchitecture of the control group (figure $2 \mathrm{~A})$; the sinusoids are devoid of inflammatory cells, the venule is clear. It showed normal liver histology. In comparison of control group with $155 \mathrm{mg} / \mathrm{kg}$ of MIE group (figure $2 B)$, there was enlargement of the central vein and marked venular congestion which is also attended by population of inflammatory cells. The sinusoids are not left out of inflammation. In contrast to Farombi et al. (2008) who stated that tetracycline has an adverse effect on the testes of the male wistar rats, the tetracycline group of $5.4 \mathrm{mg} / \mathrm{kg}$ (figure 3B), the liver showed normal architecture. The hepatocytes, the sinusoids and the venules are normal with no evidence of inflammation. In $4.8 \mathrm{mg} / \mathrm{kg}$ of tetracycline+ $83.5 \mathrm{mg} / \mathrm{kg}$ of MIE group as compared with control group (figure 4); there was enlargement of the central vein, the sinusoids are reduced in size due to central vein enlargement. In $7.7 \mathrm{mg} / \mathrm{kg}$ of Tetracycline+ $190 \mathrm{mg} / \mathrm{kg}$ of MIE group as compared with control group (figure 5); there was enlargement of the central vein which 
also shows haemorrhage, the sinusoids are not left out of inflammation.

When a substance is being consumed, in the digestion process, the substance is either beneficial or harmful to the liver. To determine liver damage, it is essential to check the enzyme activity of the liver. In this work, ALT and AST activities were employed. When the liver is injured or inflamed, the levels of ALT and AST in the blood usually rise; therefore, this test is performed to check for signs of liver disease (Pratt and Kaplan, 2000).

In the work done by Johnston, (1999); the AST: ALT was calculated by dividing the AST value by the ALT value. This procedure helps determines the liver or other organ damaged. In group $A$, which serve as the control group, the enzyme activity for ALT is $25 \pm 2.14 \mathrm{U} / \mathrm{L}$, in the reference value the activity is within normal expected value while the AST value is $89.6 \pm 1.32 \mathrm{U} / \mathrm{L}$, this value is above the expected value this might be indication of disease of the heart (Pratt and Kaplan, 2000). In group $B$, which received mango leaves decoction, the enzyme activity for ALT is $27.4 \pm 3.34 \mathrm{U} / \mathrm{L}$, in the reference value the enzyme activity is within normal expected value while the AST value is $98.8 \pm 0.56 \mathrm{U} / \mathrm{L}$, value is above the expected value. This suggests induction of hepatocellular damage. The significant increase in activity of AST and the insignificant increase activities of ALT, ALP and the level of bilirubin in serum indicate $M$. indica - induced hepatocellular damage (Izunya et al., 2010). In the group C, which were administered therapeutic dose of tetracycline, the enzyme activity for ALT is $25.5 \pm 2.15 \mathrm{U} / \mathrm{L}$, in the reference value the activity is within normal expected value showing that the drug has no adverse effect on the organ. The AST value is 87.2 $\pm 1.40 \mathrm{U} / \mathrm{L}$; the reduction in the value as compared with the control group. This shows that it is non-toxic to the organ. In group D, which was administered simultaneously mango leaves decoction and therapeutic dose of tetracycline, the enzyme activity for ALT is $25.1 \pm 1.00 \mathrm{U} / \mathrm{L}$, which is within the normal expected value while the AST value is 88.0 $\pm 0.56 \mathrm{U} / \mathrm{L}$ which is above the expected value indicating hepatic damage. In group $E$, which was simultaneously administered mango leaves decoction and therapeutic dose of tetracycline, the enzyme activity for ALT is $25.5 \pm 2.25 \mathrm{U} / \mathrm{L}$ (within the normal expected value) while that of the AST value is 88.8 $\pm 1.04 \mathrm{U} / \mathrm{L}$, this value is above the expected value and indicates hepatocellular damage. The significant increase in activity of AST as well as ALT, ALP and the level of bilirubin in serum indicate $M$. indica - induced hepatocellular damage.

In conclusion, the administration of therapeutic dose of tetracycline has no adverse effect on the cytoarchitecture and some hepatic enzyme of the liver tissues, when compared with the control group of this research. This implies that the therapeutic dose has no adverse effect on the histology of liver the wistar rats. Comparison among the groups; control, mango decoction group, tetracycline treated, tetracycline+mango treated shows that mango leaves extract has toxic effect on the liver from figures 4B\&5B. This causes enlargement and haemorrhage of the central vein, reduction in size of the sinusoids and the distortion of the hepatic cells. This shows that the mango leaves extract has adverse effect on the liver of the wistar rats. Hence, mango leaves decoction should be discontinued, research should be carried done to determine the safe dose of mango leaves decoction. 
It is a level 3 Case-control study design, randomization yes and control yes.

The potential impact of this research is that mango leaves decoction is deleterious to the liver when not taken at a safe dose.

Acknowledgement: We are greatly indebted to Dr Oladosu O.T of the Department of Biochemistry, College Health Sciences, Ladoke Akintola University of Technology, Ogbomoso, for his expertise given in the Enzyme Assay of this study.

\section{REFERENCES}

1. Berne RM, Levy MN, Koeppen BM, Stanton BA. 1998. Physiology. 4th Ed. New York: C. V. Mosby Co, p 335-36.

2. Costanzo L. 1998. Physiology.1st Ed. Philadelphia: W. B. Saunders Co, p 335-36.

3. Ekpe ED, Ebana RVB, Madunagu BE. 1990. Antimicrobial activity of four medicinal plants on pathogenic Bacteria and phytopathogenic fungi. West Afr J Biol Appl'd Chem 35: 2-5.

4. Farombi EO, Ugwuezunmba MC, Ezenwadu TT, Oyeyemi MO, Ekor M. 2008. Tetracyclineinduced reproductive toxicity in male rats effect of vitamin $\mathrm{C}$ and $\mathrm{N}$-acetylcysteine. Exp Toxicol Pathol 60: 77-85.

5. Harbourne JB. 1973. Phytochemcial Methods: A Guide to Modern Techniques on plant Analysis. 1st Ed. New York: Chapman and Hall, p 271.

6. Izunya AM, Nwaopara AO, Aigbiremolen A, Odike MAC, Oaikhena GA, Bankole JK, Ogarah PA. 2010. Morphological and Biochemical Effects of Crude Aqueous Extract of MangiferaindicaL. (Mango) Stem Bark on the Liver in Wistar Rats. Res J Appl Sci Eng Technol 2: 460-465.

7. Johnston DE. 1999. Special consideration in interpreting liver function tests. Amfam Physician; 59:2223-30.

8. Nwinuka NM, Monanu MO, Nwiloh BI. 2008. Effects of aqueous extract of Mangifera indica L. (Mango) stem bark on haematological parameters of normal albino rats. Pak J Nutr 7: 663-666.

9. Omonkhua AA, Onoagbe I.O. 2008. Effects of Irvingia grandifolia, Urena lobata and Carica papaya on the Oxidative Status of Normal Rabbits. Internet J Nutr Wellness 6: 1937-8297.

10. Pratt DS, Kaplan MM. 2000. Evaluation of abnormal liver enzyme results in asymptomatic patients. N Engl J Med 342: 1266-71.

11. Ross IA. 1999. Medicinal Plants of the World: Chemical Constituents, Traditional and Modern Medicinal Uses. Totowa: Human Press, p 234-235.

12. Uhegbu FO, Elekwa I, Ukoha C. 2005. Comparative Efficacy of crude Aqueous Extract of Mangiferaindica, carica papaya and sulphadoxinepyrimethamine on the mice infested with malaria parasite in vivo. Global J Pure Appl Sci p: 399-401.

13. Webster D, Webster M. 1974. Comparative Vertebrate Morphology. New York: Academic Press, p 364-365.

14. Widmann FK. 1980. Clinical Interpretation of Laboratory Test, 9th Ed. Washington D C: American Association of Publishers, p: 293-295. 
15. Yoshimi N, Matsunaga K, Katayama M, Yamada Y, Kuno T, Qiao Z, et al. 2001. The inhibitory effects of mangiferin a naturally occurring glucosylxanthone, in bowel carcinogenesis of male F344 rats. Cancer Lett 163:163-170.

16. Zhang Y, Li J, Wu Z, Liu E, Shi P, Han L, Guo L, Gao X, Wang T. 2014. Acute and long term toxicity of mangoes leaves extract in mice and rats. Evid Based Complement Alternat Med: $1-8$. 